\title{
血液回収自己輸血に抢けるマイトマイシンC使用に関する研究
}

\author{
福井 明* 高折 益彦* 三宅 康之** 難波 正義*** \\ * 川崎医科大学麻酔科学教室 \\ **川崎医科大学中央検査部 \\ *** 川崎医科大学実験病理学教室
}

（昭和 60 年 10 月 8 日受付）

\section{APPLICATION OF MITOMYCIN C FOR THE INTRAOPERATIVE BLOOD SALVAGING AUTOTRANSFUSION IN PATIENTS WITH MALIGNANT NEOPLASMA}

\author{
Akira Fukui*, Masuhiko Takaori*, Yasuhisa Miyake** and \\ Masayoshi Namba***
}

Cultured malignant cells, HeLa cells, human gastric cancer cells or human lung cancer cells, were exposed to either mitomycin $\mathrm{C}$ or bleomycin, concentration of which were varied from $5 \mu \mathrm{g} / \mathrm{dl}$ to $400 \mu \mathrm{g} / \mathrm{dl}$, for either 10,20 , or 30 minutes in vitro. As a result, mitomycin $\mathrm{C}$ with concentration of $200 \mu \mathrm{g} / \mathrm{dl}$ could inhibit growth and not form colony of the malignant cells on the culture media. However bleomycin showed no inhibition of the growth and colony formation of the malignant cells under the above exposures at all.

These data should be applied to intraoperative autologous blood transfusion for a case, in whom malignant cells may migrate in the salvaged red blood cells. Namely, it was advocated that $30 \mathrm{mg}$ of mitomycin $\mathrm{C}$ should be mixed with collected red blood cells concentrated in a separating ball (Haemonetics Cell Saver ${ }^{\oplus:} 250 \mathrm{ml}$ ) and should be left in place for 20 minutes for prevention of generalized dissemination of the malignant neoplasma.

It was recognized also that mitomycin $\mathrm{C}$ permeasted into the intracellular space of red cells and its concentration was about one fifth of that in the extracellular space after 20 minutes. However no change in deformability of erythrocyte was detected.

\section{要 旨}

HeLa cell, human gastric cancer cell, human lung cancer cell の 3 種類の培養悪性腫瘍細胞を

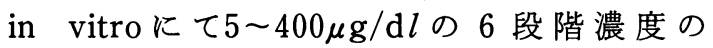
mitomycin C (MMC), あるいは bleomycin にそ れぞれ $10 ， 20 ， 30$ 分の曝露を行い, 最低有効腫瘍 細胞死隇条件を求めた。 その結果, bleomycin では いかなる条件設定でも培養液上での腫瘍細胞増 殖, コロニー形成がみとめられ, MMCについては $200 \mu \mathrm{g} / \mathrm{d} l$ 以上, 20 分間以上の曝露にて腫瘍細胞 の生育, コロニー形成はみとめられなかった。な お。, $200 \mu \mathrm{g} / \mathrm{d} l$ 以下の濃度ではたと文曝露時間を 30 分まで延長させても細胞生育阻止効果は兄られ
なかった。

この成績は血液回収自己輸血中に, 悪性腫瘍細 胞が混入する可能性のある場合に応用される。す なわち, 実地臨床使用時には, 回収赤血球が分離 ボール内 (Haemonetics Cell Saver ${ }^{\circledR}: 250 \mathrm{~m} l$ ) に集積した時点で，30mg の MMCを赤血球と混 合し，20分間放置することによってその目的を達 する。このような $\mathrm{MMC}$ 曝露中, $\mathrm{MMC}$ の一部が 赤血球内へ移行すること (曝露濃度の $1 / 5$ 量) がみ とめられたが, これにともなら赤血球機能，すく なくとも赤血球変形能には変化がみとめられな かった. 


\section{序言}

輪血後肝炎の発生，輸血用血液の不足など多く の問題を含む同種血輸血に比べ，あらゆる面で安 全性が高い自己輸血が近年見直されてきている。 当院でも図 1 に示すように Haemonetic Cell Saver ${ }^{\circledR を}$ 用いた血液回収自己輸血（Intraoperative blood salvaging autotransfusion, 以下 IAT と略す) を広範子宮全摘術，股関節全置換術 などの臼蓋形成を含む股関節手術，椎弓切除や側 弯症などの脊髄手術など臨床 40 症例以上に施行 し, 同種血輸血の回避に努めている. しかし本法 は悪性腫瘍細胞や細菌が回収される血液に混入す る場合，あるいはその可能性がある場合でも禁忌 となっている.

かつて某施設において子宮外妊娠破裂によると 思われた腹腔内出血血液の輸血を行ったところ, その回収血液中に織毛上皮腫細胞が混在していた ため, 腫瘍細胞の全身性播種を来し，患者の予後 を極めて悪化させたといら事実がある。したがっ て回収血液への腫瘍細胞の混合については特に注 意すべきものであるとともに，たとえ予想せざる 混合があってもかかる合併症を発生させないよう な工夫が必要である。

われわれは，当初輸血用マイクロフィルターを 用いて腫揚細胞の除去を試みたが，この方法では 全く目的を達し得ないことをみとめた。そこで今 回, 抗腫瘍薬を用いた IAT 血よりの腫瘍細胞を短
時間に死隇，除去する方法を企図し研究したので 報告する。

\section{方法}

I：抗腫瘍薬による腫瘍細胞除去に関する基礎 実験

抗腫瘍薬としてマイトマイシンC（以下 MMC と略す）拉よびブレオマイシン（以下 BLM と略

す）を選択し，腫瘍細胞を in vitroにおいて短時 間に死隇さすこれら薬剂有効濃度とその有効作用 時間の決定を試みた。標的腫瘍細胞には継代培養 されている人子宮頝癌の株細胞 HeLa cell, 人肺 癌の株細胞である human lung cancer cell (HLC)，人胃癌の株細胞である human gastric cancer cell (HGC),の 3 種の腫瘍細胞を用いた。

培養液は, Eagl's minimum essential medium （MEN）に牛胎児血清10\%を添加し，3 種の腫瘍 細胞をこの培養液中にて，炭酸ガス濃度 $5 \%$, 温 度 $37^{\circ} \mathrm{C}$, 湿度 $100 \%$ の条件下で培養し, 腫瘍細胞が 培養液 $1 \mathrm{~m} l$ 中に $200 \times 10^{4}$ 個以上になるまで増殖さ せた。この培養液 $1 \mathrm{~m} l$ に下記濃度になるように MMC および, BLMを混入し,クリンベンチ内に て所定時間放置した。すなわち $\mathrm{MMC}$ および $\mathrm{BLM}$ 濃度は, $5,10,50,100,200,400 \mu \mathrm{g} / \mathrm{m} l$, 曝露 時間は $10 ， 20 ， 30$ 分とした。 また対照群としては, これらの薬剤の代わりに生理食塩水を用いた。 そ して10,20,30分のクリンベンチ内での曝露を行っ た。これら処理された標的腫瘍細胞群を 3,000 回

ヘパリン2000単位

$10 \%$ クエン酸ナトリウム $10 \mathrm{~m} \ell$ $1000 \mathrm{~m} \ell$ 生理食塩水

血液リザバー

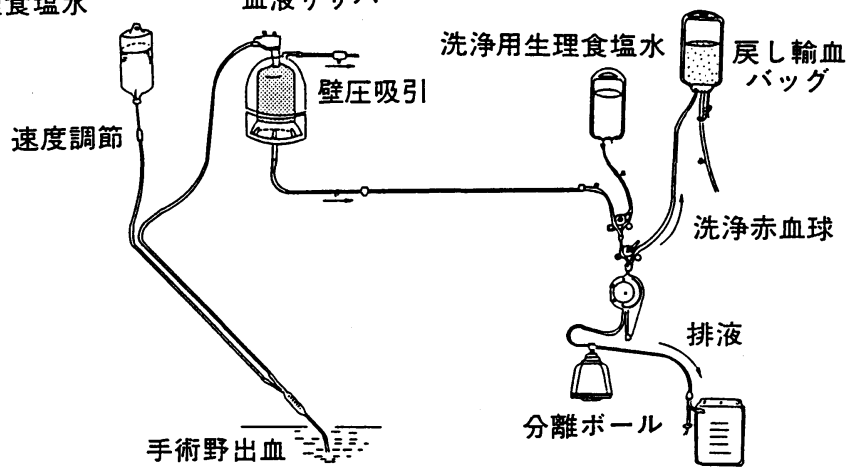

図 1 血液回収型自己輸血施行の図 (Cell Saver ${ }^{\circledR}$ 利用) 
転, 5 分遠沈にて集め, 再度新しい培養液 $10 \mathrm{~m} l$ に て 2 回洗浄後, 培養液 $5 \mathrm{~m} l$ を含む直径 $6 \mathrm{~cm}$ シャー レ内に展開, よく擋汼後, 上記炭酸ガスインキュ ベーター内で10日間培養した. 10日後, 培養細胞 をメタノールにて固定（15分間）した後，ギムザ 染色（3 時間）を行い, 生着したコロニー数を算 定した。 そしてコロニー形成のみられないものに ついては, 腫瘍細胞の死隇と判定した。

II : MMC の赤血球への取り込みに関する研究

健康成人の静脈血 $10 \mathrm{~m} l$ を採取し, 直ちに一パ リン化の後, $200 \mu \mathrm{g} / \mathrm{m} l$ の MMC $10 \mathrm{~m} l$ と十分混 和し室温にて 20 分間放置した。そして 3,000 回転, 10分間の遠沈を行い，その上澄液ならびに洗浄赤 血球に蒸留水 $1 \mathrm{~m} l$ を加えて溶血させたへモグロ ビン液の MMC 濃度を測定した。なお MMC 濃度 は, 協和醗酵工業株式会社技術部の協力を得て, 同社研究室内に颃いて生物学的検定によって測定 した。同様の実験測定は異なる実験日に計 3 回 行った.

III : MMC 曝露後 MMC の赤血球変形能に及 ぼす影響

赤血球変形能の測定は, Reidらの SchmidSchönbein 変法1を用いて行った。すなわち， 20 $\mathrm{cmH}_{2} \mathrm{O}$ の陰圧下で 1 分間に General Electric 社 製, 細孔直径 $5 \mu$ の nuclepore membrane (N500 CPRO1300)を通過する血液量を測定した。この試
験膜は厚さ $10 \mu \mathrm{m}$, 直後 $13 \mathrm{~mm}$ の円形ポリカーボ ネート膜で，直径 $5 \mu$ の円形孔が $1 \mathrm{~cm}^{2}$ あたり $4 \times$ 105個を有する。またホルダーは General Electric 社製のポリカーボネートで作られた $13 \mathrm{~mm}$ ポッ プトップ・ホルダー（FHO13PL00110）を用いた.

すなわち, ホルダーに試験膜を装置した後, $1 \mathrm{~m} l$ のガラス注射筒をホルダーに接続し，測定血液を 正確に $1 \mathrm{~m} l$ まで満たし, 図 2 の吸引瓶 (filter reservoir）中を $20 \mathrm{cmH}_{2} \mathrm{O}$ の陰圧にすると同時にス トップウォッチを作動させ, $1 \mathrm{~m} l$ の血液が試験膜 を通過する時間を測定した。この操作を同一血液 について 3 回行ってその平均値を記録し， 1 分間 に試験膜を通過する赤血球の容積を測定した。そ して以下の式を用いて変形指数 defemrmability indndex : $\mathrm{DI}^{2)}$ を算出した。

$\mathrm{DI}(\mathrm{m} l / \mathrm{min})=1 \mathrm{~m} l \times \mathrm{Ht} \times 60 / \mathrm{X}$

$\mathrm{X}$ : 血液 $1 \mathrm{~m} l$ が membrane を通過する時間 (秒)

$\mathrm{Ht}$ : ヘマトクリット值（\%)

血液と器具は $37^{\circ} \mathrm{C} に$ 保たれるように，装置をす べて $37^{\circ} \mathrm{C}$ の恒温庫に格納して行った.

検体には，健康成人 5 名の静脈血を採血しへパ リン化し，1）全血，2）生理食塩水にて洗浄した 濃厚赤血球，3） $200 \mu \mathrm{g} / \mathrm{m} l$ の MMC に20分間曝 露後, 生理食塩水にて洗浄した赤血球の 3 検体を 測定した。

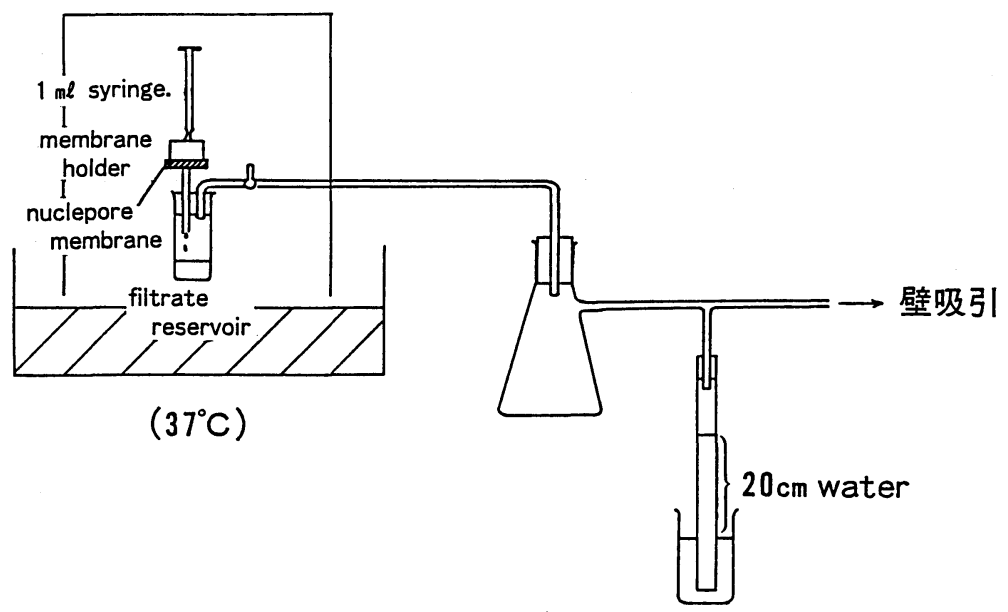

図 2 マイクロフィルター法による赤血球変形能測定装置 
統計処理は non-paired student test 用いて, すべての成績は平均士標準偏差で表示した。

\section{成}

\section{研究 I}

$5,10,50 \mu \mathrm{g} / \mathrm{m} l$ 濃度の MMC に対しては, 曝露 時間を10，20，30分と変えてもすべて対照群（コ ロニー数は無数) に等しいコロニー生着数を示し た。一方, $200 \mu \mathrm{g} / \mathrm{m} l$ の $\mathrm{MMC}$ 濃度に対しては, 20.30分の曝露によってすべて腫瘍細胞の生着を みとめなかったが，10分間の曝露では生着をみと めた。 3 種の腫瘍細胞いずれにおいても，50, 100， $200 \mu \mathrm{g} / \mathrm{m} l$ の $\mathrm{MMC}$ 濃度, $10,20,30$ 分の曝露時 間では, 曝露時間の増加, 濃度の増加に従ってュ ロ =-出現数は減少し, $200 \mu \mathrm{g} / \mathrm{m} l$ の MMC 濃度 に执いて，曝露時間20分でコロニー形成がみとめ られなくなった(表 1)。また，BLM については， $5 \sim 400 \mu \mathrm{g} / \mathrm{m} l$ までの 6 段階, $10,20,30$ 分の暴露, すべてにおいて対照群と変わらない腫瘍細胞の生 着がみとめられた。

研究 II

赤血球を浸積させた液の $\mathrm{MMC}$ 濃度は $56 \pm 7$ $\mu \mathrm{g} / \mathrm{m} l$, 生理食塩水により洗浄した後の赤血球中 の $\mathrm{MMC}$ 濃度は $12 \pm 1 \mu \mathrm{g} / \mathrm{m} l$ であって, 赤血球中 に外界濃度の約 $1 / 5$ 濃度の MMC が検出された。

研究 III

全血の DI は1.86士0.41であったが，生理食塩

表 1 各腫湯細胞に対する MMC の死隇効果( コロ 二-出現数）

\begin{tabular}{|c|c|c|c|c|}
\hline & $\begin{array}{r}M M C \text { 濃度 } \\
\text { 曝露 } \\
\mu \mathrm{g} / \mathrm{ml}\end{array}$ & 50 & 100 & 200 \\
\hline \multirow{3}{*}{$\begin{array}{l}\text { Hela cell } \\
(\mathrm{n}=5)\end{array}$} & 10 & $25 \pm 8$ & $12 \pm 3$ & $3 \pm 1$ \\
\hline & 20 & $22 \pm 8$ & $6 \pm 2$ & $0 \pm 0$ \\
\hline & 30 & $12 \pm 3$ & $7 \pm 2$ & $0 \pm 0$ \\
\hline \multirow{3}{*}{$\begin{array}{l}\text { HGC cell } \\
(n=5)\end{array}$} & 10 & $14 \pm 4$ & $4 \pm 1$ & $4 \pm 1$ \\
\hline & 20 & $14 \pm 2$ & $4 \pm 2$ & $0 \pm 0$ \\
\hline & 30 & $7 \pm 1$ & $3 \pm 2$ & $0 \pm 0$ \\
\hline \multirow{3}{*}{$\begin{array}{c}\text { HLC cell } \\
(\mathrm{n}=5)\end{array}$} & 10 & $7 \pm 1$ & $4 \pm 1$ & $1 \pm 1$ \\
\hline & 20 & $6 \pm 1$ & $3 \pm 1$ & $0 \pm 0$ \\
\hline & 30 & $5 \pm 2$ & $1 \pm 1$ & $0 \pm 0$ \\
\hline
\end{tabular}

(mean $\pm \mathrm{SD})$
表 2 赤血球変形能指数 (D.I)

$(n=5)$

\begin{tabular}{|c|c|c|c|}
\hline & 全血 & 洗浄赤血球 & $\begin{array}{c}\mathrm{MMC} \text { 曝露後 } \\
\text { 洗浄赤血球 }\end{array}$ \\
\hline $\begin{array}{l}\text { D.I. } \\
\mathrm{m} l / \mathrm{min}\end{array}$ & $1.86 \pm 0.41$ & $126.93 \pm 10.99$ & $126.08 \pm 14.99$ \\
\hline
\end{tabular}

水にて洗浄した赤血球の DI $126.93 \pm 10.99$, $200 \mu \mathrm{g} / \mathrm{m} l$ の MMC に20分間曝露後, 生理食塩水 にて洗浄, 遠心した濃厚赤血球の DI は, 126.08土 14.99であり, 後 2 者間に有意差はみとめられな かった（表 2 ).

\section{考 察}

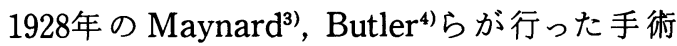
野へ出血した血液を回収し再利用する自己輸血 は，種々の污染物質が輸血用血液中に混入される ため，合併症が多く過去約40年間全く顧みられる ことがなかった。しかしながら赤血球洗浄をきわ めて効率的に行いらる Cell Saver ${ }^{\circledR}$ (Haemonetics）や赤血球よりも大きな細胞や異物を除去 しらる輸血用マイクロフィルターなどの出現によ り, 安全に手術野出血血液回収自己輸血を実施で きるようになってきた，当院では昭和58年より， Haemonetics Cell Saver ${ }^{\circledR}$ 用いた本法と，血液 希釈自己輸血とを併用することによって術中，術 後を通じて患者の安定した循環動態と末梢への酸 素供給を維持し, 同種血輸血の回避に努力してき た ${ }^{5) \sim 8)}$.

しかし本法には，前述したごとく悪性腫瘍細胞 の全身性播腫の危険性を伴わないわけではない。 そこでもし回収赤血球に混入する悪性腫瘍細胞を 捕捉するか，もしくはこれを速やかに死隇させる 方法が開発されれば，たとえ対象者に予想せざる 悪性腫瘍が存在していて，これが回収赤血球中に 混入するようなことがあっても，患者に危険をも たらすような事態の回避が可能となろら，それゆ えにわれわれは，MMC あるいは BLM を用いて 腫瘍細胞を速やかに死隇させる方法を試みて，上 記の結果を得た。

これらの抗腫瘍薬を大量間欠投与法として成人 に対して用いるときは，MMCで10〜20mg/週 
$\gtrless^{9) 10} \mathrm{BLM}$ で15〜30mg/週 $\times 2^{11)}$ 静脈内に投与 する.この投与量では投与直後, 静脈血内で $4 \sim 15$ $\mu \mathrm{g} / \mathrm{m} l$, 組織液 (細胞外液) 中で $1 \sim 3 \mu \mathrm{g} / \mathrm{m} l$ の濃 度に達し, 癌細胞に対して増殖抑制作用を発揮す るものと云われている。一方, in vitroにおいて腫 瘍細胞を死隇さす MMC の濃度に関する報告は 少なく, MMC, BLM との接触時間, 特に短時間 接触時間における腫場細胞死隇効果について研究 した報告はほとんどみとめられない。したがって 悪性腫場を有する患者に括いて手術野出血血液回 收自己輸血をMMC あるいはBLM を用いて安 全に施行するには，使用する MMC，あるいは BLM の濃度とそれぞれに曝露する時間との決定 が必要であった。

われわれが行った第 I の研究で, MMC 濃度 200 $\mu \mathrm{g} / \mathrm{m} l, 20$ 分間の曝露で腫瘍細胞の増殖, コロ ニー形成はみとめられなかった。この濃度を臨床 例, すなわち Haemonetics Cell Saver ${ }^{\circledR}$ 回路内に 扣ける MMC の腫瘍細胞死隇に応用して誤りが ないものと判定された。

しかるにBLM 処理によっては，われわれが 行った, $5 \sim 400 \mu \mathrm{g} / \mathrm{m} l, 10 \sim 30$ 分の曝露時間では 全く腫瘍細胞の死隇を来すことができなかった。

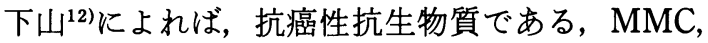
BLM は両者とも, 殺細胞作用が濃度依存性であ り, 速効性かつ遅効性群の type Ib に分類され，ま た作用機序も二重鎖 DNA と結合し，架橋形成を 行らとされている.MMC で増殖, コロニー形成が みとめられなかったにもかかわらず, BLM でこ れがみとめられた理由として，以下の点が考えら れた。すなわち，1）MMC と同濃度，同曝露時間 を用いたこと（実施臨床ではさらに高濃度, 長時 間曝露は不可能であるが).2） MMC が quinome, methyl urethane, aziridine の 3 つの抗癌活性基 を持っているため広い抗癌スペクトルを有してい るが, BLM は $\mathrm{SH}$ 化合物, あるいは $\mathrm{H}_{2} \mathrm{O}_{2}$ の存在 下で活性化されるという特性を有し, 成熱型扁平 上皮癌に有効であるスベクトル範囲の問題. 3）検 査対象とした悪性腫瘍細胞に対する適合性の問 題. などが考えられた ${ }^{13)}$.

MMC による腫瘍細胞死滅, 除去の実施は以下
のごとくである.すなわち，赤血球回収により図 1 の分離ボール(容量 $250 \mathrm{~m} l$ )が注ぼ赤血球で満た される時に $30 \mathrm{mg}$ の $\mathrm{MMC}$ をのボール内に注入 し， 1 ～ 2 分間，分離ボールを回転させることに より，MMC と赤血球を充分に混合させる。そして 後から回収された血液のボール内注入を停止し， 20分間静止状態で MMCを腫瘍細胞に作用させ る（分離ボール容量は $250 \mathrm{~m} l$ であるが，平均赤血 球濃度が $50 \%$ であるので, 腫瘍細胞が浮遊する自 由空間は $125 \mathrm{~m} l$ となる。そこで実質, 腫瘍細胞が 接する $\mathrm{MMC}$ 濃度は約 $200 \mu \mathrm{g} / \mathrm{m} l$ となる)。その 後通常使用量5) 2 ～ 3 倍，すなわち 2,000 $3,000 \mathrm{~m} l$ の生理食塩水にて連続的に赤血球を洗 浄し，直ちに戻し輸血バックに移し，濃厚赤血球 $100 \mathrm{~m} l$ に対し MMC 20mg を添加し腫瘍細胞の死 隇効果を強化している。

MMC の赤血球生成系への影響については,

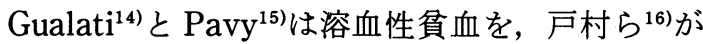
再生不良性負血を指摘報告している。しかし， MMC が in vitro で直接赤血球そのものに対して の影響，たと兄ば赤血球の酸素運搬能，赤血球変 形能の変化などに関する報告は皆無に等しい。 MMC が上記曝露によって赤血球表面に結合，あ るいはその中に浸透しているものであれば，この ような赤血球の生理的機能に影響を及ぼすものと 考光，赤血球への MMC 吸収について検討した。 その結果, 外界濃度の約 $1 / 5$ 量の MMC が赤血球 にみとめられた。この MMC が赤血球のいずれの 部分に存在するのかは今後の研究によらなければ ならないが, 最も可能性の高いものは赤血球表面 への付着であろら。もしそれが事実であった場合， 赤血球膜に変化を生じ，それが赤血球変形能に変 化を与えるとすれば，微少循環に打ける酸素運搬 体としての赤血球機能が失われる結果も招きかね ない。この点に鑑み，われわれはまず赤血球変形 能についての検討を行ったが， MMC 曝露後洗浄 赤血球と, 洗浄赤血球の赤血球変形能との間に有 意差はみとめられず，MMC 処理赤血球を自己輸 血した場合でも末梢微小循環系に拈けるこの赤血 球血管内通過性に問題を生じるような事態は発生 しないと考えてょいと思われる。 
ちなみにわれわれは MMCを用いた腫瘍細胞 除去法を既に 5 症例に実施している。このうち 3 症例は転移性脊髄腫瘍患者(未分化癌)， 2 症例は 転移性脊髄腫瘍患者 (腺癌) で, いずれも椎弓切 除術が施行された。洗浄赤血球からの腫瘍細胞診 (オートスメア法)は 5 例すべてに拈いて実施して いるが，これらの症例に対して行われた自己輸血 用血液から腫瘍細胞は全く発見されなかった。む ろん，現在の時点で自己輸血に起因したと思われ る腫瘍細胞播種の症状も全くみとめられていな い.

\section{まとめ}

今回，われわれは血液回収自己輸血中に混入す る悪性腫瘍細胞を死隇させる方法として MMC を用いることを試みた。すなわち回収赤血球が分 離ボール内に集積した時点で30mgの $\mathrm{MMC}$ を赤 血球と混合する方法を関発した。

本法を行ら基礎研究として, HeLa Cell, HGC, HLC の 3 種類の培養悪性腫瘍細胞を用いて in vitroにて 5 $400 \mu \mathrm{g} / \mathrm{m} l$ の 6 段階濃度の MMC, あるいは BLM に $10,20,30$ 分の 3 種の曝露を行 い, 最低有効腫瘍死隇条件を求めたところ, BLM ではいかなる条件設定にも腫瘍死隇効果が得られ ず, $\mathrm{MMC}$ に拈いては $200 \mu \mathrm{g} / \mathrm{m} l, 20$ 分間の上記条 件を得た。このような $\mathrm{MMC}$ 曝露中, $\mathrm{MMC}$ は一 部, 赤血球内への移行 (培養液濃度の $1 / 5$ 量) がみ とめられたが, これに伴ら赤血球機能, 少なくと も赤血球変形能の変化はみとめられなかった。

謝辞 本研究の組織培養技術のご指導をいただいた，川 崎医科大学組織培養免疫センターの北昭子氏はじめ同セ ンターの方々に感謝します。

本稿の要旨は, 第33回日本輸血学会総会, 1985,5 月(東 .京）において発表した。

\section{文献}

1) Reid, H.L., Barnes, A.J., Lock, P.J., Dormandy,
J.A. and Dormandy, T.L.: Asimple method for measuring erythrocyte deformability. J. Clin. Pathol., 29: 855-858, 1976.

2）沖野 實, 三宅康夫, 木村 潔, 安永幸二郎： 、 イクロフィルター法による赤血球変形能の基礎的 検討. 臨床血液, $21: 925-931,1980$.

3) Maynard, R.L. and Rees, W.T.: A case of ruptured extrauterine pregnancy treated by autotransfusion. J.A.M.A., $92: 1758-1759,1929$.

4) Butler, H.B.: Auto-blood-transfusion in two cases of ruptured tubal pregnancy. Brit. Med. J., $2: 1000-1008,1929$.

5）高折益彦, 福井 明, 奥坊康士：自己輸血. 麻酔, $34: 530-550,1985$.

6）中山雅人, 小川重男, 高折益彦：拡大血液希釈性 自己輸血に関する研究. 日本輸血学会雑誌, 30 : 168-174, 1984.

7）高折益彦, 中山雅人：同種輸血節减のための各法 とその比較。日本輸血学会雑誌, $30 ： 284-286$, 1984.

8）高折益彦，新谷潤二：同種輸血節减のための各法 とその比較。外科診療, $27: 309-316,1985$.

9）田口鐵男編集：マイトマイシン一癌化学療法の歩 みとともに一．協和企画通信, 東京, 1984, pp. 191-195.

10）古江 尚, 田口鐵男：抗癌剤の選び方, 使い方, 医学書院, 東京, 1980, pp. 22-32.

11）松永藤雄, 久保明良：がん化学療法の実際. 南江 堂, 東京, 1971, pp. 56-59.

12）下山正徳：制癌剤の Cell-kill-kinetics と至適投 与法. 癌と化学療法, 3:1103-1110, 1976.

13）古江 尚, 太田和雄, 田口鉄男, 藤田 洗, 塚越 茂: 癌化学療法の基礎と臨床(第 2 版), 癌と化学 療法社, 東京, 1973, pp. 205-211.

14) Gualati, S.C.: Microangiopathic hemolytic anemia observed after treatment of epidermoid carcinoma with mitomycin $\mathrm{C}$ and 5 -fluorouracil. Cancer, $45: 2252-2257,1980$.

15) Pavy, M.D.: Hemolytic-uremic syndrome associated with mitomycin therapy. Cancer Treat. Rep., 66: 457-461, 1982.

16）戸村隆訓, 滝沢義矩, 入交清博: Mytomycin C K よる再生不良性負血と腎障害をきたした 2 症例。 癌の臨床, $12: 173-176,1966$. 